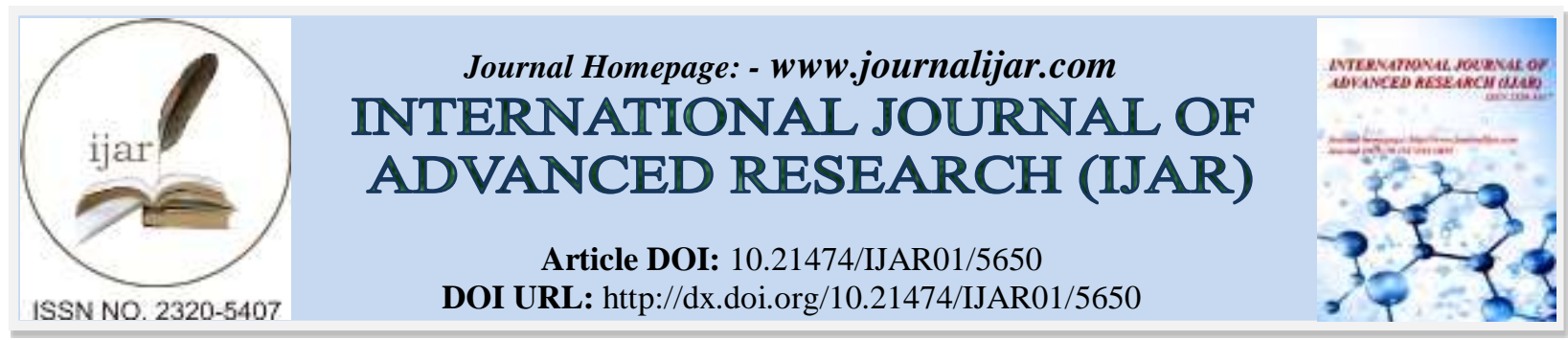

RESEARCH ARTICLE

\title{
LOCATION AND DESIGN ASPECTS IN CULINARY CENTER BUILDING DESIGN DEVELOPMENT FOR BUSINESS SUSTAINABILITY OF STREET VENDORS IN SURABAYA, INDONESIA.
}

Siti Azizah.

Department of Architecture, Institut Teknologi Adhi Tama Surabaya, Indonesia.

\section{Manuscript Info}

Manuscript History

Received: 17 August 2017

Final Accepted: 19 September 2017

Published: October 2017

Key words:-

Location, Design, Culinary Center, business sustainability.

\begin{abstract}
Surabaya City Government has a policy to handle local street vendors problem by relocating them into one place that called Culinary Center. Until now, the Surabaya City Government has built many culinary centers in several locations in Surabaya and will continue to build because it is the optimal solution for the problem of street vendors in Surabaya. In fact, some culinary centers have many customers but the others are quiet. If a Culinary Center is out of business, they will return to the old place and the problem of street vendors in Surabaya will happen again.

The aim of this research is to know the aspects of location and design of Culinary Center building based on the users wants. Users are street vendors and culinary centers customers. So, it can be develop a representative Culinary centers model for sustainability of street vendors business on it. The aspects are includes aspects of location, shape, interior, outdoor space and supporting activities from several culinary centers in Surabaya.

This research using qualitative research design with research and development technique. Furthermore, the data collection technique is using quantitative research design by spread the questionnaires. Then, the analysis is done descriptively. In the beginning of the research, researcher will identify the aspects that affects the sustainability of business street vendors based on the users wants. From the questionnaires results of the users, it can be develop the basic model of culinary centers building for "Terminal Manukan", Surabaya, Indonesia, as the object of this study
\end{abstract}

Copy Right, IJAR, 2017,. All rights reserved.

\section{Introduction:-}

Surabaya City Government has a policy in handling city problems for street vendors by relocation to one place that is Culinary Center. Until the beginning of 2017 there have been 43 culinary centers in several locations in Surabaya and will continue to grow because the culinary center is the optimal solution for the problem of street vendors in Surabaya. From some culinary centers that has been there, some culinary centers have many customers but there is also ones that have few customers so that culinary center is threatened to out of bussiness. If a culinary center out of bussiness so the street vendors will return to the old place and problems of street vendors repeat again. This research is to know the aspect of location and design that the users want for the sustainability of culinary Sentra business. This research will knowing aspects in the arrangement of culinary center in accordance with the the users want.

\section{Resources:-}

In the review of the elements of the city according to Appleyard (1989), there are 3 attributes to form the building image: 
1. Attribute Shape

2. Consists of contour, facade, color, bright surface.

3. Visual Attribute

4. That is the ease of building to be seen.

5. Attributes of use and their relation.

Consists of the intensity of use and historical linkage. according to Hamid Shirvani (1985), the design of the city has eight interrelated elements: Land Use, Building Form and Massing, Circulation and Parking, Open Space, Pedestrian ways, Activity Support, Signage and Preservation. Street vendors are included in the elements of Support Activities defined as elements / potentials that support certain activities, according to Shirvani that Supporting Activities is an element of the city that supports several centers located in the city center that has considerable service. In terms of form, Supporting Activities can be divided into two, they are:

1. Supporting Activities open space is pedestrian-activity, park, recreation, city park, street vendor area, area seller of art goods, etc.

2. Supporting Activities in Closed Space / buildings, is a retail store, department store, public library and so forth.

From the explanation of the street vendors are included in the element of supporting activities open space. Besides that Support Activities can provide image / visual image that is typical in certain urban areas, because it can present a local identity. Alisjahbana (2003) argues that the informal sector in urban areas has positive and negative aspects. The positive aspect of the informal sector is that they can be a solution to the problem of labor. and the negative aspect is because they cause the environment to become slum. Meanwhile, according to Boonjubun (2017) street vendors have the rights of street vendors. : the right to information, the right to place, the right to participate in the planning process, the right of residence, the right to earn a living, and the right to permanent property by applying for the right of harmful ownership.

Yatmo (2008) sees street vendors as an "in-place element " by understanding the context of their presence on the premises, and considering potential vendors as local identities, so it is important to recognize the context of their presence in urban planning, which can be considered in determining planning policies, dismantling and eviction of street vendors. In relation to this location, Widjajanti (2016) concludes that space utilization based on location characteristics is a strategic location, main activity, accessibility and convenience. the activity of street vendors grows and develops in urban space due to the influence of major area activities in which they are located (McGee and Yeung, 1977). After many time Culinary Center development in Surabaya has been implemented, according to Carlina (2013), Some Culinary Center experiencing different conditions, there are many visited by customers but there is a culinary center have few customers (customers less than 25 people per day).

\section{Methodology:-}

The research method used is qualitative research with Research and Development method. While taking the data using quantitative methods in the form of questionnaires. According Sugiyono (2011) Research and Development Method is a research method used to produce a particular product, and test the effectiveness of the product. As the case of research is Culinary Center built by Surabaya City Government in Surabaya City. Research is done in several steps or processes. Questionnaires were distributed to 10 randomly selected culinary centers in eastern Surabaya, North Surabaya, Central Surabaya, West Surabaya and South Surabaya. Respondents are users of culinary centers. They are street vendors and customers culinary centers. Total respondents of street vendors are 28 people. And Total respondents customer culinary center are 50 people. Aspects studied are:

1. Location

2. Aspect of design: building form, Room atmosphere inside, exterior, and

3. Support activities in the culinary center

After recapitulation of the questionnaire results to ten culinary centers in Surabaya, then made a model of design development at the Culinary Center terminal manukan in Surabaya, Indonesia

\section{Result:-}

The culinary center in Surabaya until early 2017 has built 43 units. In addition to enjoying various culinary activities, some culinary centers have supporting activities for turn on it. According to the observation that there are several culinary centers have supporting activities like stage of musical entertainment and sports facility. 
The following is the result of the recapitulation of questionnaires to respondents that are culinary center users in Surabaya.

Location Aspect:-

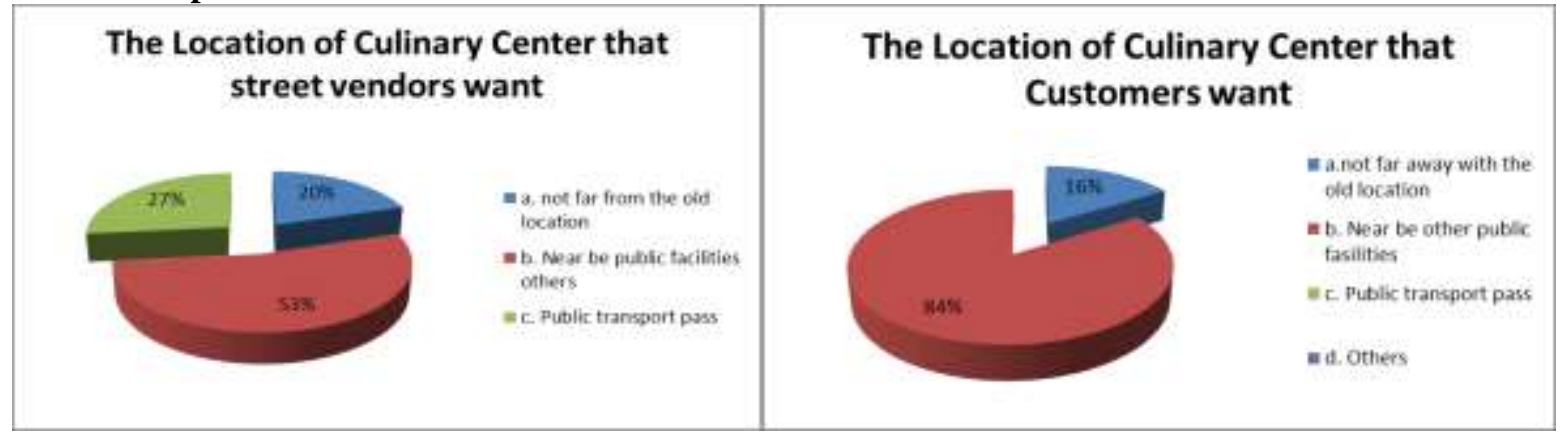

Fig.1:- The location of culinary centers that users want

Average users likes the location of a culinary center near be other facilities

Aspect of Design:-

building form:-

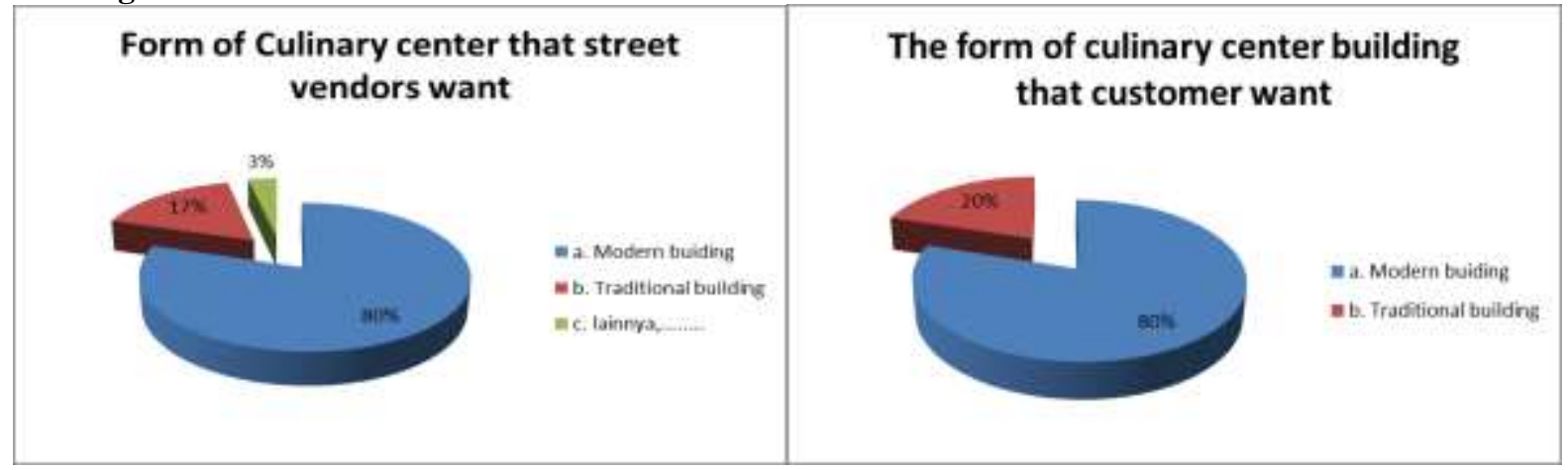

Fig.2:- The form of the culinary center building that users want

The average user likes the form of a modern building as a form of culinary center building

Interior:-

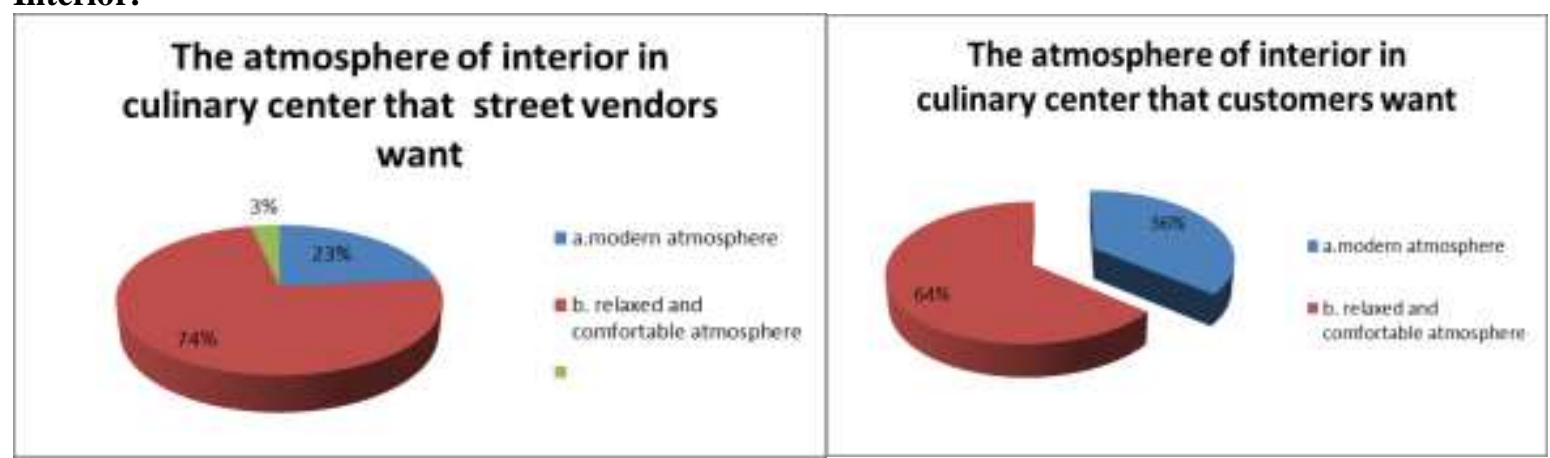

Fig. 3:- The atmosphere of interior in culinary center that users want The average user likes the atmosphere of a relaxed and comfort interior 
Outdoor Space:-

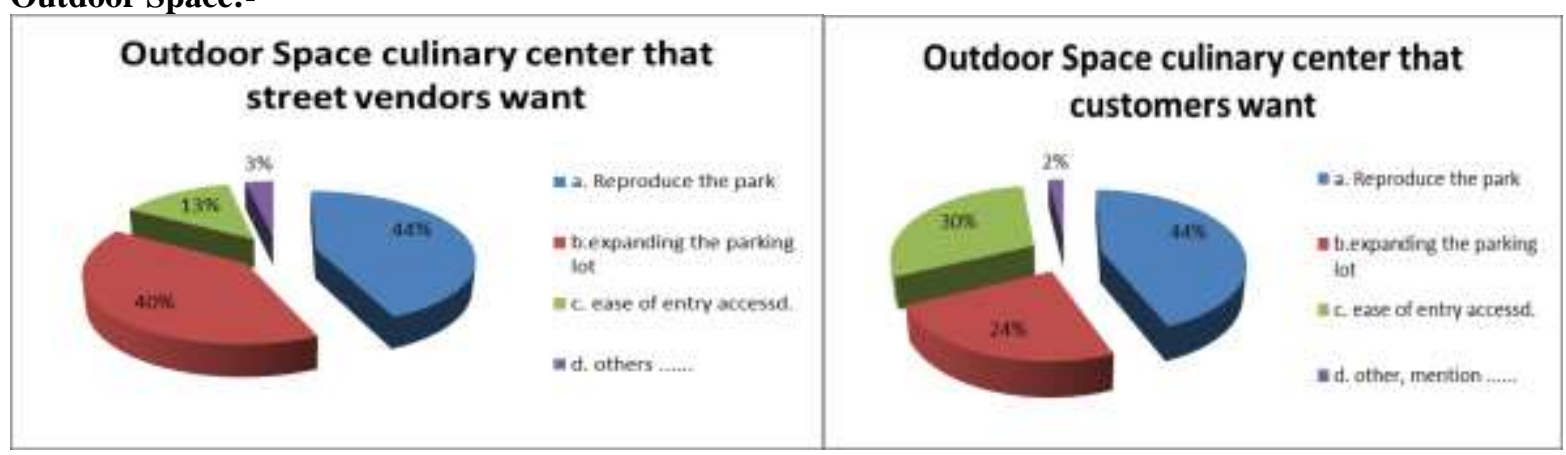

Fig. 4:- Outdoor space culinary center that Users want

The average user likes an outdoor space that has lots of garden and shade

Supporting Activities In The Culinary Center

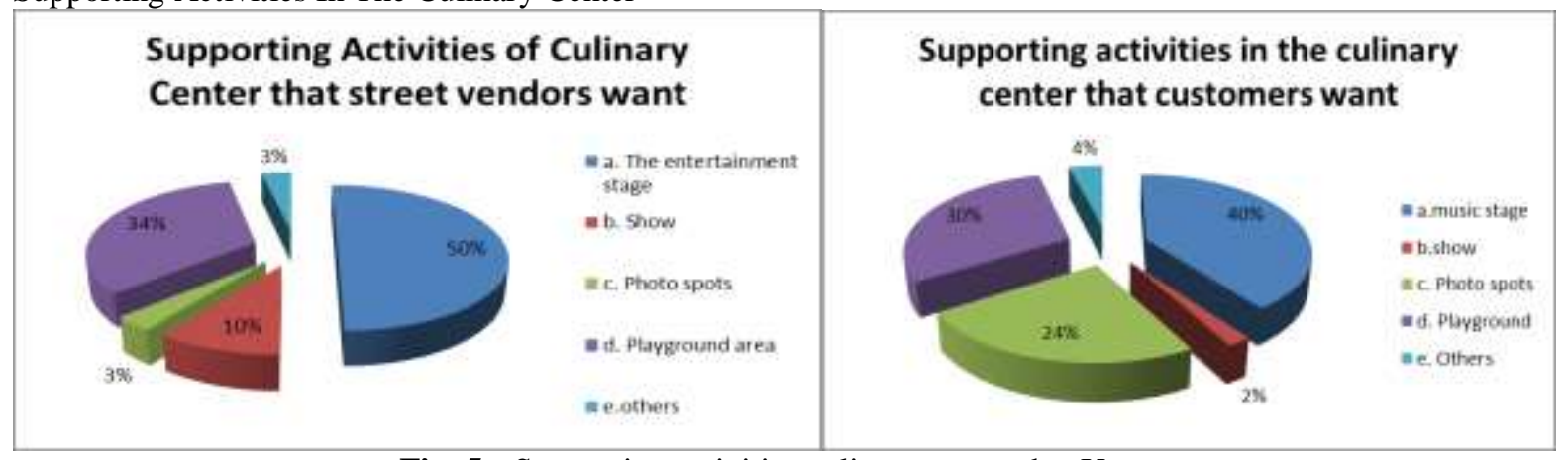

Fig. 5:- Supporting activities culinary center that Users want

The average user likes the supporting activity in the form of a musical entertainment stage

\section{Discussion:-}

Questionnaire Results in the form of Respondents Desire from Users average culinary center in Surabaya about the location and design of culinary center building, applied in the culinary center Terminal Manukan in Surabaya, Indonesia. Culinary center Terminal Manukan is one of the culinary centers in Surabaya located in West Surabaya. The location of this culinary center close to the local transportation station Manukan.

Design Development Model at Culinary Center Manukan in Surabaya:

\section{\begin{tabular}{|l|l} 
BEFORE & AFTER
\end{tabular}}

\section{LOCATION}

Users want the location of the culinary center close to public facilities, At this culinary center close to the local transportation station makes this place is appropriate because it is visited by many visitors terminal Manukan

\section{BUILDING DESIGN}

a. BUILDING FORM
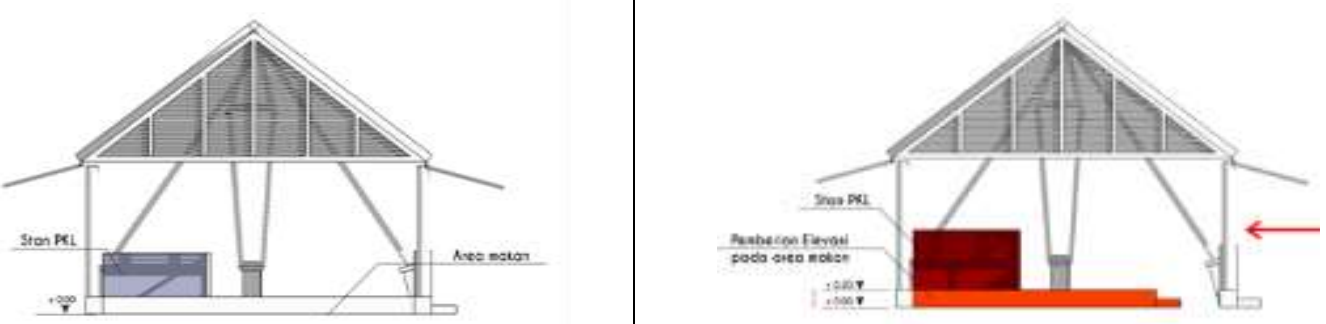

The development of the forms includes the facade of modern culinary centers such as the food court in general. By using a red accent on the street vendors. The shape retains the open shape for smooth air circulation. 


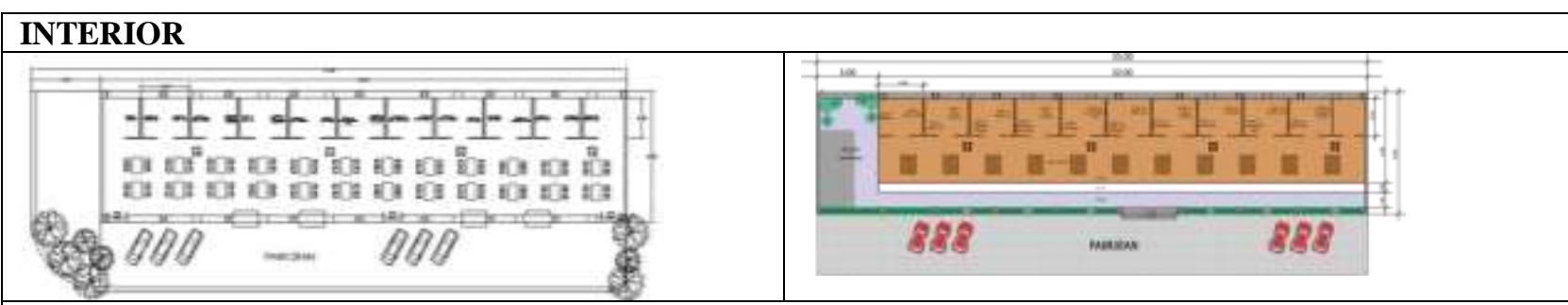

The interior design of the existing culinary center tends to be monotonous. Arranging the interior by arranging the merchandise booth position back and forth to be more dynamic and not boring and memorable more relaxed as users want

\section{c. OUTDOOR SPACE}
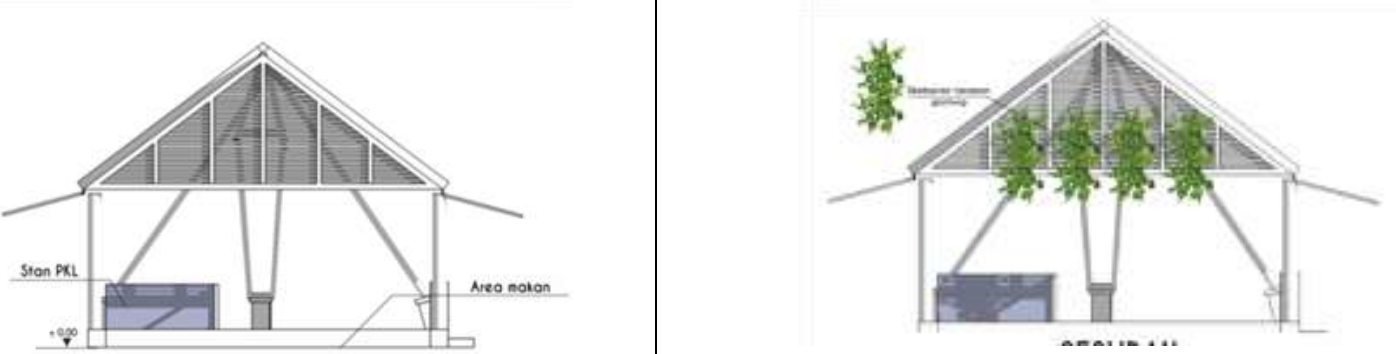

Users want to expand the outer space by multiplying the plant expanding the parking lot because the existing parking lot is inefficient for users. Then made a hanging plant for outdoor space memorable green and cool. Also because the main entrance is too low the same as the parking lot then the development by making the main entrance and dining area made higher.

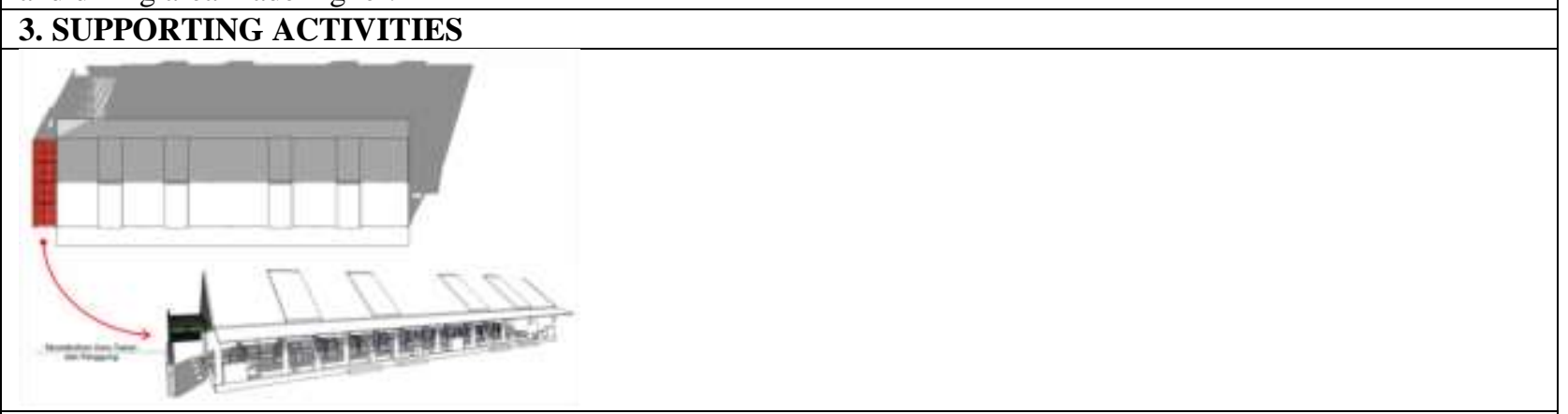

Respondents want to have supporting activities in the form of stage performances. Existing entertainment can be traditional performances such as ludruk or musical entertainment and so on

\section{Conclusion:-}

The results obtained on the aspect of location and design (form, interior, exterior and supporting facilities) at the culinary center according to the users want. Users (street vendors and customers) in several culinary centers Surabaya showed the same desire. This result is applied to the development of culinary center building design of terminal manukan namely:

1. Location close to public facilities

2. Modern shape

3. Dynamic and relaxed on the interior

4. Green and shady impression that looks from the outside

5. there is an entertainment stage 


\section{References:-}

1. Alisjahbana, 2003, Urban Hidden Economy, ITS, Surabaya

2. Appleyard, Donald, 1989. "Why Building Are Known" Environment and Behavior, Berkeley of California

3. Boonjubun, Chaitawat, 2017, Conflicts over streets: The eviction of Bangkok street vendors, journal homepage: www.elsevier.com/locate/cities

4. Dinas Koperasi dan UMKM Pemerintah Kota Surabaya, 2016, Compilation of General Regulations for street vendors and merchants in Culinary Tourism Center,

5. McGee, T.G and Y.M. Yeung. (1977). Hawkers in Southeast Asian Cities, Planning for the Bazaar Economy. Ottawa: IDRC.

6. Reynita Carlina, 2013, 5 Sentra kuliner di Surabaya, DetikNews 29-09- 2013, http://news.detik.com/read/2013/09/29/114606/2372426/475/2/ini-dia-5-sentra-kuliner-di-surabaya\#bigpic

7. Shirvani, Hamid, 2010, Urban Design Process, Van Nostrand Reinhold Company (first published 1985), New York.

8. Sugiyono, 2011, Research method of Quantitative, Qualitative and R\&D, Alfabeta cv, Bandung

9. Widjajanti, Retno, 2016, The space utilization by street vendors based on the location characteristics in the education area of Tembalang, Semarang, Procedia - Social and Behavioral Sciences 227

10. Yatmo, Yandi Andri. (2008). Street Vendors as Out of Place Urban Elements. Journal of Urban Design, Vol.13 No.13, 387-402, October 2008. 